\title{
DENTAL MATURITY AS AN INDICATOR OF CHRONOLOGICALAGE: RADIOGRAPHIC ASSESSMENT OF DENTAL AGE IN A BRAZILIAN POPULATION
}

\author{
Lucio Mitsuo KURITA ${ }^{1}$, Alynne Vieira MENEZES ${ }^{2}$, Marcia Spinelli CASANOVA ${ }^{3}$, Francisco HAITER-NETO ${ }^{4}$
}

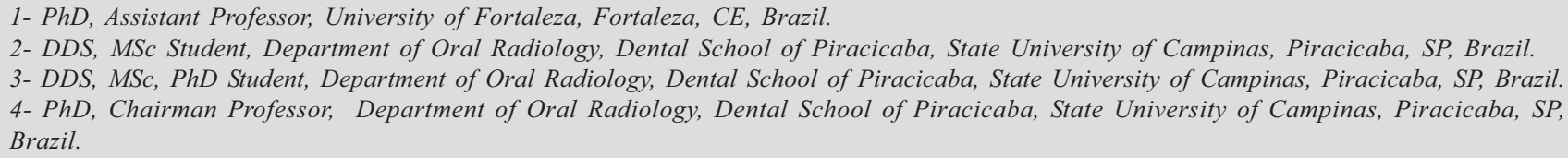

Received: November 22, 2005 - Modification: December 14, 2006 - Accepted: March 27, 2007

\begin{abstract}
$O$

bjective: The purpose of this investigation was to evaluate the applicability of the methods proposed by Nolla and by Nicodemo and colleagues for assessing dental age and its correlation to chronological age. Methods: Panoramic radiographs of 360 patients from the city of Fortaleza (CE, Brazil) aged 7-15 years were used to assess the associations between dental and chronological age. Data were submitted to statistical analysis using the BioEstat 2.0 (2000) software. Student-Neuman-Keuls test was performed and Pearson's correlation coefficients were calculated at 5\% significance level. Results: When the Nolla method was applied, the mean difference between true and estimated age for males and females was underestimated. The use of the method proposed by Nicodemo and colleagues also resulted in underestimation, although it was more evident in male subjects. The correlation coefficients between chronological age and estimated dental age were high, with mean values ranging between 0.87 and 0.91 for males and between 0.84 and 0.93 for females. Conclusion: Although both methods proved to be reliable in estimating age, the use of correction factors is recommended.
\end{abstract}

Uniterms: Age determination by teeth; Panoramic radiography; Diagnostic imaging.

\section{INTRODUCTION}

Variations in human growth patterns arise from complex genetic and environmental interactions. Variability is expressed clinically as differences in the timing and intensity of growth events, so that children vary in the ages at which they reach stages of physical development. Well-defined indicators of physiological maturity provide a more reliable basis than chronological age for the assessment of growth potential, especially during the puberty growth spurt. In dentistry, the knowledge of physiological maturation is particularly useful as a diagnostic tool to determine the most appropriate time and method for orthodontic treatment, as well as to determine the need and the best time for surgery procedures $^{23}$.

The development of each individual can be affected by genetic, racial, nutritional, climate, hormonal and environmental factors ${ }^{12,14,18}$. In view of this, some authors ${ }^{14,19}$ have recommended the acceptance of the normal parameters between different regions. The development of secondary sexual features, mental age, tooth mineralization and eruption, height-weight relationship and bone development are some of the adjunctive methods used to determine the developmental stage. For some authors, bone development is the most reliable method ${ }^{23}$. On the other hand, others emphasize the superiority of the degree of dental mineralization, which is less affected by external factors ${ }^{7,18}$.

Some authors have advocated the applicability of the bone age determination method ${ }^{8,10}$, while others endorsed the applicability of the dental age determination method $^{1,3,4,9,22,26,27}$. Yet, others ${ }^{13}$ have applied a combination of both in different populations.

Numerous studies have been developed to estimate dental age $e^{5,16,21}$. In Brazil, emphasis is placed on studies that describe a chronological table of permanent tooth mineralization in the Brazilian population ${ }^{15,17,20}$. The methods used to determine dental age have been developed according to different individual features of tooth growth and 
development in the populations of northeastern Brazil. Based on the differences in these populations, the goal of this study was to determine the dental age of children in northeastern Brazil and compare the results with those of established methods. In addition, the use of correction factors will assessed for allowing the clinical application of the study results.

\section{MATERIAL AND METHODS}

The study population consisted of 360 healthy patients of both genders aged 7 to 15 years from the city of Fortaleza (CE, Brazil), who were assisted at the Radiology Clinic of the University of Fortaleza. The research protocol was approved by the Ethics in Research Committee of the University of Fortaleza.

The children were assigned to 18 groups $(n=20$, being 10 male and 10 female) according to the chronological age. At the time of radiographic examination, the chronological age of each child was calculated on the basis of the child's reported date of birth. Before the study began, the investigator performed a calibration exercise. The final statistical analysis was applied when the result of the intraexaminer test was considered as adequate. Using Dalberg's formula $\left(\mathrm{e}=\sqrt{ } \sum(\mathrm{m} 1-\mathrm{m} 2) 2 / 2 \mathrm{n}\right)$, the error was 0.41 months.

Dental age was assessed by panoramic radiographs according to the methods proposed by Nolla ${ }^{22}$ (1960) and Nicodemo, et al. ${ }^{21}$ (1974). In the Nolla method, the stage of development of the mandibular left teeth of each child was analyzed and then compared to a series of standardized drawings depicting 10 stages of tooth calcification for each gender. Therefore, dental age estimation was obtained for each patient. A similar procedure was used for the method proposed by Nicodemo, et al. ${ }^{21}$ (1974). However, this method did not take the patient's gender into consideration.

Data were tabulated and submitted to statistical analysis using the BioEstat 2.0 (2000) software. Student-NeumanKeuls test was performed and Pearson's correlation coefficients were calculated at 5\% significance level.

\section{RESULTS}

The relationship between chronological and estimated dental age was evaluated by each method, gender and age groups, as well as in the total population by analysis of means and standard deviation.

Table 1 shows that the mean chronological age for boys was 135.94 months ( \pm 30.40 , range $85.30-186.30)$ and for girls was 135.97 months ( \pm 30.93 , range $83.80-186.40)$.

In boys, the mean dental ages were underestimated in both methods, and the differences were quite marked for the older groups. However, both methods showed similar values in almost all studied groups. In girls, the mean dental age was underestimated for almost all groups using the Nolla $^{22}$ (1960) method. On the other hand, the use of the method proposed by Nicodemo, et al. ${ }^{21}$ (1974) showed that, although the tendencies for chronological age were greater than those for dental age, the ages in both genders were essentially the same (Figure 1).

Table 2 shows the difference between chronological age and dental age for both methods and for male and female subgroups using the Student-Neuman-Keuls test and the Pearson correlation coefficient, which revealed high and statistically significant $(\mathrm{p}<0.05)$ values. Thus a high correlation between dental age and chronological age can be assumed.

Figures 2 and 3 show the scatter plots and the straight line and curves adjusted for regression equations between estimated dental age (X) and chronological age (Y), for each method and gender studied. Additionally, the respective determination coefficients $\left(\mathrm{R}^{2}\right)$ were obtained, which present the amount of total variation expected for each method, and the regression equations that should be used to make the method applicable to the studied population.

\section{DISCUSSION}

Children with the same chronological age may show differences in the developmental stages of different biologic systems. These differences have led to the concept of physiological age as a means to define progress toward completeness of child's development or maturity. Thus, physiological age, or its frequently used synonyms, biological and developmental age, are measures for describing the status of an individual child, whereas chronological ages convey only a rough approximation of this status because of the range in development observed for any given age. Physiological age is estimated by the maturation of one or more tissue systems, and dentition is one of the systems used ${ }^{11,16}$.

Dental age correlates closely with chronological age in children development. Studies have shown that dental development relates more closely to chronological age than skeletal, somatic or sexual maturity indicators ${ }^{12}$. Tooth formation has been more widely used than tooth eruption for assessing dental maturation because it is a continuous and progressive process that can be followed radiographically, and most teeth can be evaluated at each examination. When information about the formation stages of several teeth is combined, the dental age of an individual can be estimated ${ }^{22}$. There are several methods for estimating dental age, among them, the method proposed by Nolla ${ }^{21}$ (1960), which has been the method of choice over the years ${ }^{7,9,24}$, and the method proposed by Nicodemo, et al. ${ }^{20}$ (1974), which has been developed taking into consideration the Brazilian population ${ }^{1}$.

There is extensive documentation on the differences between different populations relative to the age for determining dental maturation markers, mostly tooth eruption, which makes ethnicity a quite attractive factor. Other less tangible factors, such as climate, nutrition, socioeconomic levels and urbanization, may also influence 
maturation rates ${ }^{13}$. Therefore, considering the regional differences in a country like Brazil, establishing specific parameters for each region would be extremely valuable. In the present study, the applicability of two dental age determination methods was assessed for the Brazilian northeast population.
The 82-189-month age range was chosen because most maturity changes occur during this period.

Different types of radiographs, like oblique cephalogram and intraoral radiographs, have been used to investigate dental development, but the panoramic radiographs used in the present study have been adopted by most authors due

TABLE 1- Means (in months) and standard deviation (SD) of chronological age and estimated dental age using the methods proposed by Nolla and Nicodemo, et al. for Brazilian boys and girls

\begin{tabular}{|c|c|c|c|c|c|c|c|c|c|c|c|c|c|}
\hline $\begin{array}{l}\stackrel{0}{0} \\
\frac{0}{3} \\
\frac{0}{0}\end{array}$ & $\begin{array}{l}\text { Age ranges } \\
\text { (months) }\end{array}$ & $\begin{array}{l}\text { Chronc } \\
\text { Age }\end{array}$ & ological & $\begin{array}{l}\text { Boys } \\
\text { Nicode } \\
\text { et al. }\end{array}$ & emo, & Nolla & & $\begin{array}{l}\text { Chronc } \\
\text { Age }\end{array}$ & ological & $\begin{array}{l}\text { Girls } \\
\text { Nicode } \\
\text { et al. }\end{array}$ & mo, & Nolla & \\
\hline & & Mean & SD & Mean & SD & Mean & SD & Mean & SD & Mean & SD & Mean & SD \\
\hline 1 & $82-87$ & 85.30 & 2.01 & 82.80 & 8.49 & 86.40 & 8.00 & 83.80 & 1.99 & 93.60 & 15.80 & 87.60 & 17.02 \\
\hline 2 & $88-93$ & 90.60 & 1.71 & 86.40 & 9.47 & 92.40 & 5.80 & 91.20 & 1.66 & 88.40 & 6.05 & 84.00 & 7.59 \\
\hline 3 & $94-99$ & 96.40 & 1.69 & 91.60 & 6.05 & 96.00 & 7.59 & 96.20 & 2.22 & 101.30 & 10.58 & 92.00 & 13.42 \\
\hline 4 & $100-105$ & 102.00 & 1.70 & 94.80 & 8.89 & 94.80 & 3.79 & 102.30 & 1.82 & 96.00 & 5.12 & 90.00 & 6.27 \\
\hline 5 & $106-111$ & 108.70 & 1.64 & 100.80 & 14.09 & 103.20 & 6.20 & 108.80 & 1.77 & 101.50 & 11.61 & 99.70 & 9.01 \\
\hline 6 & $112-117$ & 114.00 & 1.99 & 98.70 & 10.00 & 99.60 & 8.49 & 114.20 & 1.48 & 113.30 & 16.00 & 108.00 & 14.70 \\
\hline 7 & $118-123$ & 120.50 & 1.69 & 116.70 & 14.29 & 112.40 & 11.09 & 120.50 & 1.83 & 117.00 & 9.05 & 107.00 & 8.02 \\
\hline 8 & $124-129$ & 126.80 & 1.66 & 128.70 & 31.79 & 113.50 & 12.43 & 125.60 & 1.69 & 127.60 & 8.09 & 116.70 & 5.61 \\
\hline 9 & $130-135$ & 131.90 & 1.10 & 122.40 & 11.03 & 118.80 & 13.21 & 132.60 & 1.69 & 124.40 & 9.71 & 117.80 & 10.49 \\
\hline 10 & $136-141$ & 139.10 & 1.83 & 131.10 & 8.76 & 129.40 & 11.70 & 138.80 & 2.23 & 135.30 & 12.11 & 125.50 & 12.43 \\
\hline 11 & $142-147$ & 144.80 & 1.54 & 137.50 & 11.61 & 132.90 & 18.63 & 144.40 & 1.78 & 136.80 & 14.09 & 129.60 & 12.39 \\
\hline 12 & $148-153$ & 150.60 & 1.43 & 133.20 & 19.14 & 132.00 & 24.00 & 150.70 & 1.42 & 146.40 & 9.47 & 136.80 & 8.39 \\
\hline 13 & $154-159$ & 156.50 & 1.75 & 138.50 & 27.55 & 145.10 & 25.43 & 156.00 & 1.49 & 153.60 & 17.71 & 139.20 & 15.18 \\
\hline 14 & $160-165$ & 162.20 & 1.87 & 153.60 & 13.62 & 150.00 & 12.96 & 162.40 & 2.40 & 160.00 & 21.63 & 148.00 & 19.90 \\
\hline 15 & $166-171$ & 169.00 & 1.83 & 160.00 & 6.00 & 156.00 & 14.70 & 168.40 & 1.91 & 160.00 & 14.84 & 152.00 & 19.74 \\
\hline 16 & $172-177$ & 174.30 & 1.68 & 151.60 & 9.71 & 149.50 & 9.84 & 174.70 & 2.10 & 161.50 & 18.87 & 146.20 & 12.94 \\
\hline 17 & $178-183$ & 179.30 & 1.64 & 162.00 & 6.31 & 163.20 & 18.93 & 180.30 & 2.00 & 162.00 & 12.96 & 153.60 & 13.62 \\
\hline \multirow[t]{2}{*}{18} & 184-189 & 186.30 & 0.95 & 174.00 & 14.14 & 170.40 & 19.43 & 186.40 & 1.51 & 173.30 & 23.32 & 162.70 & 20.00 \\
\hline & Total & 135.9 & 30.40 & 125.87 & 29.51 & 125.30 & 28.63 & 135.97 & 30.83 & 130.71 & 29.95 & 122.15 & 27.87 \\
\hline
\end{tabular}

TABLE 2- Statistical correlation between chronological and estimated dental age for both genders

\begin{tabular}{|c|c|c|c|c|c|c|}
\hline & & Male & & & Female & \\
\hline & $\begin{array}{l}\text { Chronological } \\
\text { age (a) }\end{array}$ & $\begin{array}{l}\text { Nicodemo, } \\
\text { et al. (b) }\end{array}$ & Nolla (b) & $\begin{array}{l}\text { Chronological } \\
\text { age (a) }\end{array}$ & $\begin{array}{l}\text { Nicodemo, } \\
\text { et al. (b) }\end{array}$ & Nolla (b) \\
\hline $\begin{array}{l}\text { Chronological } \\
\text { age }\end{array}$ & 1.000 & & & 1.000 & & \\
\hline $\begin{array}{l}\text { Nicodemo, } \\
\text { et al. }\end{array}$ & $0.899 * 1.000$ & & & $0.894^{*}$ & 1.000 & \\
\hline Nolla & 0.870 & $0.933^{*}$ & 1.000 & $0.888^{*}$ & $0.940^{*}$ & 1.000 \\
\hline
\end{tabular}

Different letters indicate statistically significant difference by Student-Newman-Keuls test at $5 \%$ significance level. 
to their accessibility and the possibility to visualize all teeth ${ }^{2,6,17,24,26}$. The mandibular teeth were chosen because they can be easily visualized on the panoramic radiograph. Several authors ${ }^{1-3,17,19,21}$ have shown that there are no significant differences between the right and left sides and that the rate of growth was approximately the same on both sides. However, further comparison of the various studies is virtually impossible because of the many differences in methodology, age groups and sample sizes.

The relationship between chronological and estimated dental ages was evaluated for each studied method, gender and age range, as well as, for the total sample, by analysis of means and standard deviation.

In boys, the mean dental ages were underestimated in both methods, and the differences were quite marked for
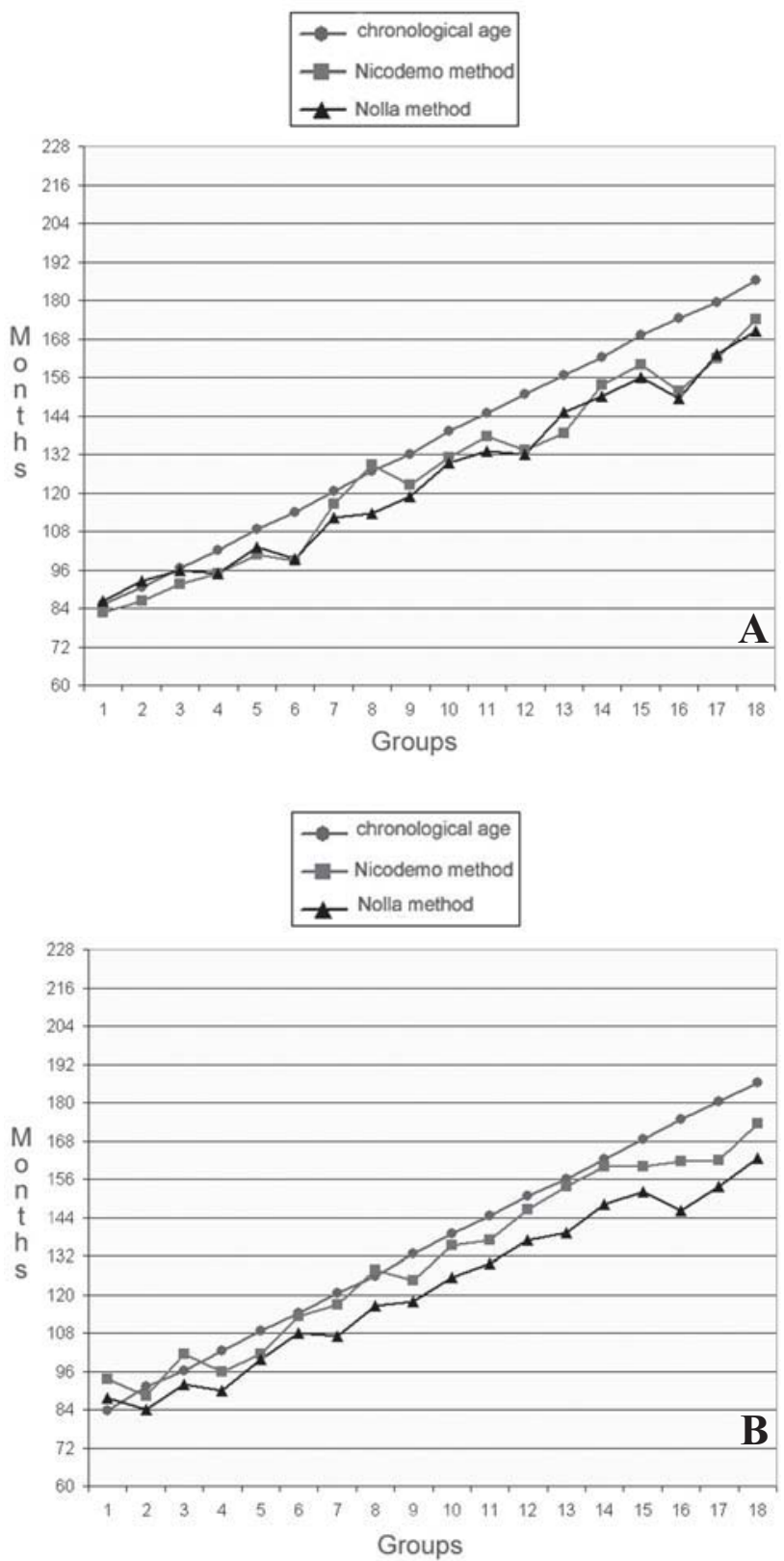

FIGURE 1- Correlation between chronological and estimated dental age using the methods proposed by Nolla and Nicodemo, et al. A: males; B: females. the older groups. Both methods showed similar values in almost all groups. In girls, the mean dental age was also underestimated in almost all groups using the Nolla method. On the other hand, when the method proposed by Nicodemo and colleagues were used, it was observed that, although the tendencies for the chronological age were greater than those for the dental age, the ages were essentially the same when compared to the male population data. This difference probably occurred because this method uses the same parameter for both genders, not taking into account the female precociousness. Similar results have been reported by other authors, such as Nolla ${ }^{21}$ (1960), Daito, et al. ${ }^{3}$ (1989), Carvalho, et al. ${ }^{2}$ (1990) and Ferreira Júnior, et al. ${ }^{6}$ (1993). Only Moraes ${ }^{17}$ (1974) and Araújo ${ }^{1}$ (2000) found no significant difference between genders.

Small signs of differences in dental development have been seen among different populations. Nÿstron, et al. ${ }^{22}$ (1988) reported that differences in overall dental maturity exist not only among nations but also among groups of children in a nation with a relatively homogenous population. The underestimated dental age found in the population of the present study was not observed by Souza Freitas, et al. ${ }^{25}$ (1970), who reported an overestimation in younger children and an underestimation in older-age children of southeast Brazil using Nolla method. Another
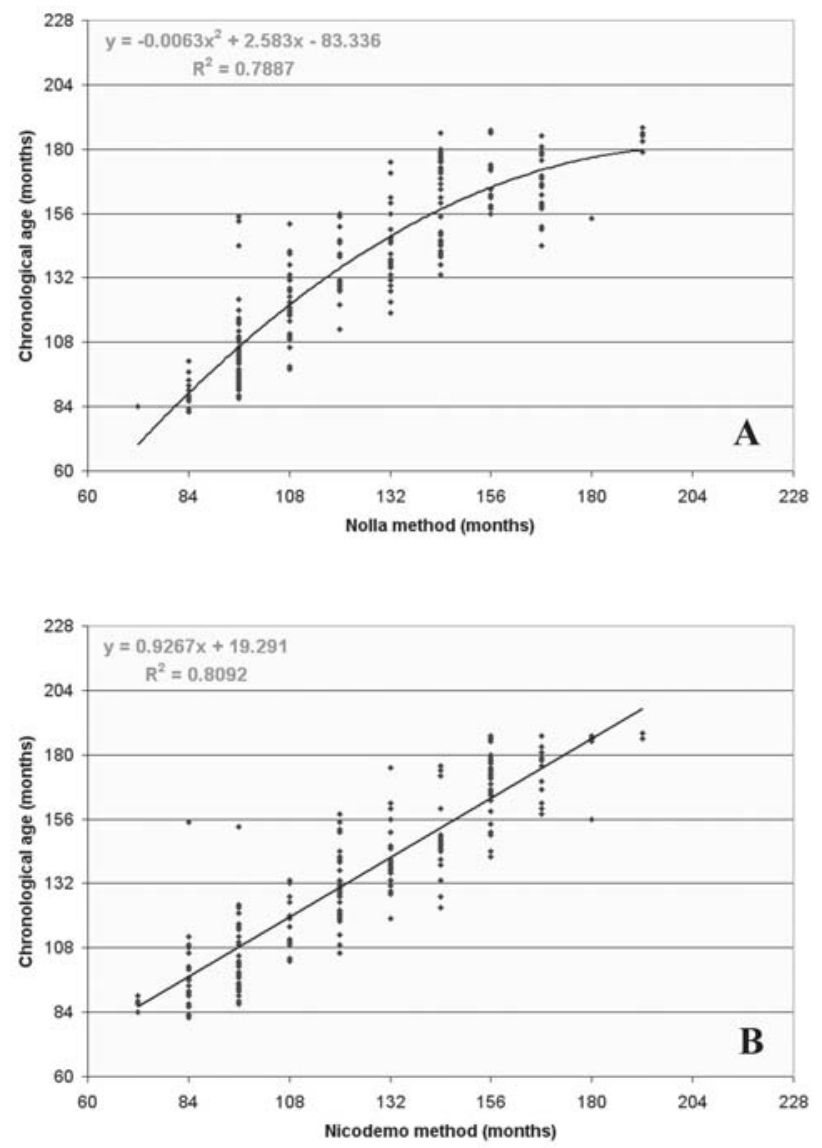

FIGURE 2- Scatter plots and straight line and curves adjusted for regression equations between estimated dental age $(\mathrm{X})$ and chronological age $(\mathrm{Y})$ obtained by both methods for Brazilian boys. A: Nolla method; B: Nicodemo's, et al. method. 
$\operatorname{study}^{4}(1994)$ showed that dental age was significantly higher than chronological age among Chinese children, whereas Moraes ${ }^{17}$ (1974) found a delay in the first and later stages, the dental age being greater than the chronological age. Finally, Holtgrave, et al. ${ }^{9}$ (1997) reported no difference in girls using the Nolla method; in boys, however, dental development was accelerated, being most apparent in very young males.

Only Araújo ${ }^{1}$ (2000), using the method proposed by Nicodemo, et al. ${ }^{21}$ (1974) to study a sample of children from the state of Maranhão, in northeastern Brazil, showed that dental development was delayed when compared to chronological age. A possible explanation for this could be the similarity between our sample and the sample from Araújo's study ${ }^{1}$, with respect to nutritional, environmental and socioeconomic conditions.

According to Tompkins ${ }^{27}$ (1996) and Stefanac-Papic, et al. ${ }^{26}$ (1998), differences in dental development could exist between different ethnic groups. Furthermore, Moorrees ${ }^{16}$ (1963), Nanda and Chawla ${ }^{19}$ (1966), Moraes ${ }^{17}$ (1974) and Nyströn, et al. ${ }^{22}$ (1988) emphasized that the methods of conversion to dental ages depend on the population at issue. Therefore, adaptations might be applied for each region. In view of this, correction factors must be established to make
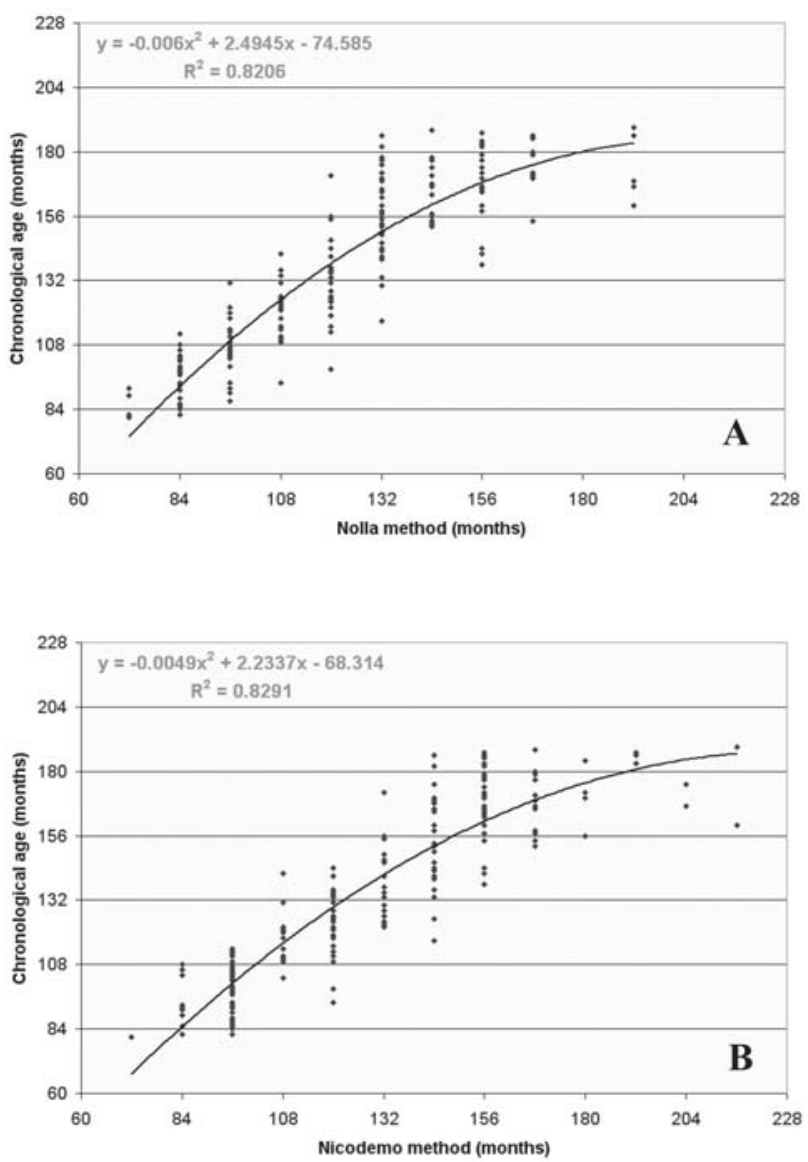

FIGURE 3- Scatter plots and straight line and curves adjusted for regression equations between estimated dental age $(\mathrm{X})$ and chronological age $(\mathrm{Y})$ obtained by both methods for Brazilian girls. A: Nolla method; B: Nicodemo's, et al. method. the methods proposed by Nolla ${ }^{22}$ (1960) and by Nicodemo, et al. ${ }^{21}$ (1974) applicable to each studied population.

\section{CONCLUSIONS}

- In boys, a high correlation between chronological and dental age was observed. There was no significant difference between both methods, however, significant difference was observed between the estimated dental age and the chronological age.

- Girls showed accelerated formation of permanent teeth and higher mean dental age than boys. There was significant difference between both methods and between the chronological and the estimated dental age.

- For each studied method, the values of correction factors (regression equations) were established and might be used to improve the applicability to the studied population.

\section{ACKNOWLEDGEMENTS}

The authors wish to thank Ellen Vaut, instructor in the Harvard University ESL program, for assistance with aspects of English grammar.

\section{REFERENCES}

1- Araújo MMA. Cronologia da mineralização dos dentes canino, pré-molares e segundo molar permanentes inferiores, entre maranhenses de seis a quatorze anos de idade [tese]. São José dos Campos (SP): Faculdade de Odontologia de São José dos Campos, Universidade Estadual Paulista; 2000.

2- Carvalho AAF, Carvalho AA, Santos Pinto MC. Estudo radiográfico do desenvolvimento da dentição permanente de crianças brasileiras com idade cronológica variando entre 84 a 131 meses. Rev Odontol UNESP. 1990;19:31-9.

3- Daito M, Kawahara S, Tanaka M, Imai G, Nishihara G, Hieda T. Calcification of the permanent first molars observed in panoramic radiographs. J Osaka Dent Univ. 1989;23(1):45-55.

4- Davis PJ, Hagg U. The accuracy and precision of the "Demirjian System" when used for age determination in Chinese children. Swed Dent J. 1994;18(3):113-6.

5- Demirjian A, Goldstein H, Tanner JM. A new system of dental age assessment. Hum Biol. 1973;45(2):211-27.

6- Ferreira ER Júnior, Santos-Pinto LAM, Santos-Pinto R. Estágio de mineralização dental: análise comparativa entre sexos. Rev Odont UNESP. 1993;22(2):303-13.

7- Green LJ. The interrelationships among height, weight and chorological, dental and skeletal ages. Angle Orthod. 1961;31:18993.

8- Guzzi BSS, Carvalho LS. Estudo da maturação óssea em pacientes jovens de ambos os sexos através de radiografias de mão e punho. Ortodontia. 2000;33(3):49-58.

9- Holtgrave EA, Kretschmer R, Muller R. Acceleration in dental development: fact or fiction. Eur J Orthod. 1997;19(6):703-10. 
10- Koc A, Karaoglanoglu M, Erdogan M, Kosecik M, Cesur Y. Assessment of bone ages: is the Greulich-Pyle method sufficient for Turkish boys? Pediatr Int. 2001;43(6):662-5.

11- Leurs IH, Wattel E, Aartman IH, Etty E, Prahl-Andersen B Dental age in Dutch children. Eur J Orthod. 2005;27(3):309-14.

12- Lewis AB, Garn SM. The relationship between tooth formation and other maturational factors. Angle Othod. 1960;30(2):70-7.

13- Mappes MS, Harris EF, Behrents RG. An example of regional variation in the times of tooth mineralization and hand-wrist ossification. Am J Orthod Dentofacial Orthop. 1992;101(2):14551 .

14- Marcondes E. Idade óssea em pediatria. Pediatr. 1980;2:297311

15- Medici E Filho. Cronologia da mineralização dos caninos, prémolares e segundos molares permanentes entre brasileiros leucodermas. Rev Fac Odontol Sao Jose Campos. 1974;3(1):57-64.

16- Moorrees CF, Fanning EA, Hunt EE. Age variation of formation stages for ten permanent teeth. J Dent Res. 1963;42(6):1490-502.

17- Moraes LC. Cronologia da mineralização dos incisivos e primeiros molares permanentes entre leucodermas brasileiros da região sudeste. Rev Fac Odontol Sao Jose Campos. 1974;3(1):65-71.

18- Moraes L, Médici E Filho, Castilho JCM, Leonelli ME. Idade óssea. RGO (Porto Alegre). 1994;42(4):201-3.

19- Nanda RS, Chawla TN. Growth and development of dentitions in Indian Children. I. Development of permanent teeth. Am J Orthod. 1966;52(11):837-53.

20- Nicodemo RA, Moraes LC, Médici FE. Tabela cronológica da mineralização dos dentes permanentes entre brasileiros. Rev Fac Odontol Sao Jose Campos. 1974;3(1):55-6.

21- Nolla CM. The development of permanent teeth. J Dent Child $1960 ; 27(4): 254-66$

22- Nystrom M, Ranta R, Kataja M, Silvola H. Comparisons of dental maturity between the rural community of Kuhmo in northeastern Finland and the city of Helsink. Community Dent Oral Epidemiol. 1988;16(4):215-7.

23- Perry JHT, Damico F. Época de tratamento ortodôntico relacionada com o "spurt" de crescimento facial. Ortodontia. $1972 ; 5(3): 123-31$.

24- Sierra AM. Assessment of dental and skeletal maturity: a new approach. Angle Orthod. 1987;57(3):194-208.

25- Souza Freitas JA, Tavano O, Álvares LC, Lopes ES. Aplicação odonto-legal de algumas tabelas cronológicas da evolução dental. Estomatol Cult. 1970;4(2):181-200.

26- Stefanac-Papic J, Alkadri KZ, Legovic M, Galic N. Comparison of dental maturity between two ethnic groups. Coll Antropol. 1998;22:123-6.

27- Tompkins RL. Human population variability in relative dental development. Am J Phys Anthropol. 1996;99(1):79-102 